\title{
Marx 1845 or the Fateful Rejection of Anschauung
}

\begin{abstract}
One of Karl Marx's strongest condemnation is that of Ludwig Feuerbach's intuitivecontemplative materialism in his Theses of 1845 . This condemnation famously leads him to an understanding of human activity as purely objective and of "revolution" as praxis, that is, as a "practical-critical" activity exclusively based on reason and reason alone. The question that is rarely asked about this condemnation is this: what is lost in this abandonment of the intuitive-contemplative on the way to historical materialism? The aim behind this question is purely speculative. It does not intend to provide yet again a historical reading of this famous turning point in Marx's move away from Feuerbach. It simply intends to see whether something could be gained instead from revisiting Feuerbach's understanding of the intuitivecontemplative and whether this could allow us to move beyond the 21 st Century deadlock of Marx's "rational praxis." In terms of reading, the essay will concentrate not only on Marx's Theses and the "works of the break," but also on key aspects of Feuerbach's understanding of intuition-contemplation, as well as contemporary readings of this major turning point in history, especially those in the French Marxist tradition such as Bloch, Henry, Althusser, Macherey, and of course, Balibar.
\end{abstract}

\section{Keywords}

Marx, Feuerbach, Praxis, Intuition, Anschauung, Materialism

\section{Introduction: The Condemnation}

One of Karl Marx's strongest condemnation is that of Ludwig Feuerbach's intuitivecontemplative materialism in his famous Theses of 1845 . The disapproval is crystal clear: "[Feuerbach] does not grasp the significance of 'revolutionary,' of 'practical-critical,' activity." (Marx and Engels 2008, 69). Engels follows suit in The German Ideology with a much more acerbic vilification of the famously recluse philosopher. He writes: "The entire philosophy of Feuerbach amounts to... a passive adoration of nature and enraptured kneeling down before its splendour and omnipotence." (Marx and Engels 1976, 11). But this isn't all, Engels sees in Feuerbach one of the many "sheep, who take themselves (and are taken) for wolves... their bleating merely imitates, in a philosophical form, the concepts of the German middle class..." (Marx and Engels 1976, 23). By the time Marx and Engels elaborate their own interpretation of materialism, Feuerbach is basically a philosopher who "achieved nothing positive beyond a turgid religion of love and a meagre, impotent morality." (Marx and Engels 2008, 247). This damaging condemnation of Feuerbach has persisted ever since. As Zawar Hanfi, who introduces the most well-known edited collection of texts by Feuerbach in English summarises: "Marx drifts away from Feuerbach... leading [him] to the elaboration of a concept of man that... transcends the scope of the contemplatively limited anthropology of Feuerbach." (Feuerbach 2012). 1845 thus sounds the death toll for Feuerbach and his works.

This condemnation is often interpreted as a major turning point in the development of Marx's ideas. For example, Louis Althusser, as is well known, calls Marx and Engels writings of the 
period, "the Works of the Break." (Althusser 2005, xxxiii). Another major commentator on these early works, Etienne Balibar, also confirms the importance of this hinge in the philosophical thought of Marx and Engels. He writes: "the Theses are symptomatic of the theoretical revolution (or "epistemological break") through which Marx would have dropped an essentially Feuerbachian 'humanist' understanding of communism to adopt a scientific (non ideological) problematic of social relations and class struggles as the motor of history." (Balibar 2012). Feuerbach's condemnation thus signals a new departure for Marx away from a seemingly "bourgeois" contemplation of nature towards a scientific materialism often called "dialectical."

While much has been written about this famous turning point, little has been said of the one key element of this condemnation: As the quotes above show, the condemnation focuses not just on a blanket repudiation of all previous "humanist" and "bourgeois" materialisms, including that of Feuerbach, but much more specifically on a rejection of an approach to materialism that is considered "intuitive-contemplative," in German, Anschauung. Marx's first Theses on Feuerbach is here indicative of this specific rejection. He writes:

"The chief defect of all hitherto-existing materialism - that of Feuerbach included - is that the thing, reality, [and] sensuousness (der Gegenstand, die Wirklichkeit, Sinnlichkeit) are conceived only in the form of the object (Objekts) or of intuition/contemplation (Anschauung), but not as human sensuous activity, practice (Praxis), not subjectively." (Marx and Engels 2008, 69).

Marx's point is clear: the three key elements of materialism, namely, "the thing, reality, and sensuousness" can be apprehended neither as an object of reason nor intuitivelycontemplatively (Anschauung). It must be approached instead as activity, as praxis. Marx confirms this again in the fifth thesis, when he writes:

"Feuerbach, not satisfied with abstract thinking, wants intuition-contemplation (will die Anschauung); but he does not conceive sensuousness as practical, human-sensuous activity." (Marx and Engels 2008, 70).

Marx's vocabulary is unequivocal: Feuerbach "wants" intuition-contemplation (Anschauung) because on the one hand, abstraction has failed him and on the other, he is incapable of conceiving materialism as praxis. In other words, Feuerbach "needs..." (will die...) the grounding that intuition-contemplation (...Anschauung) provides without realising that it is praxis that grounds materialism. ${ }^{1}$ The 1845 condemnation of Feuerbach's work thus hinges on this "bourgeois" blindness to see human activity as the only basis for materialism.

In a typically less nuanced manner, Engels also confirms the rejection of intuitivecontemplative approaches to materialism when he writes: "Feuerbach's 'conception' of the sensuous world is confined on the one hand to mere contemplation of it, and on the other to mere feeling..." (Marx and Engels 1976, 39). The aim of both Marx and Engels' critique of Feuerbach's intuitive-contemplative approach is to highlight that materialism can only be understood as the product of industry and not as the outcome of an unproductive (and thereby simply intuitive-contemplative) apprehension of reality. As is well known, materialism is exclusively for them a historical product, the result of the activity of a whole succession of generations, each standing on the shoulders of the preceding one, developing its industry and its intercourse, and modifying its social system according to changed needs. Because it rests 
on a seemingly unproductive ground (Anschauung), Feuerbach's own take on reality is thereby idealistic and defective and can only therefore be abandoned.

But it is not just Feuerbach who is dismissed for relying on an intuitive-contemplative (Anschauung) approach to materialism. As is well known, during the same period, Marx also dismisses Hegel's own intuitive-contemplative approach. In the strongest of terms, Marx writes in "Critique of the Hegelian Dialectic and Philosophy as a Whole" that Hegel's aim in The Encyclopaedia Logic is only to turn an abstract thought into a materialist one on the sole basis of a meaningless "feeling." He writes:

"[Hegel's] entire transition from logic to natural philosophy is nothing else but the transition... from abstracting to intuiting (Anschauen). The mystical feeling which drives the philosopher forward from abstract thinking to intuiting is boredom - the longing for content." (Marx 2007, 167).

For Marx then, Hegel's materialism is based on an empty intuition-contemplation that effectively serves nothing, except a bored longing for some real content. With this corollary condemnation of Hegel's philosophy, Marx thus confirms his deliberations with Feuerbach that intuition-contemplation (Anschauung) is only a trick that allows "bourgeois" philosophers to claim some kind of purchase on reality, when in fact, it only serves to confirm their own abstract thoughts totally un-anchored in real life.

Considering such condemnations, the question that inevitably begs to be asked here is this: What is lost and/or what is gained from this condemnation of intuition-contemplation? The question is obviously not: why intuition-contemplation is no longer a viable approach to materialism. Marx's entire work clearly attest to the problems incurred by this exclusive reliance on intuition-contemplation as an abstract ground for materialism. The question is more precisely: what does Marxist materialism lose with such a rejection and what might it possibly gain if it is reconsidered it anew? If one of the declared aims of Marx's 1845 Theses on Feuerbach is to come up with a type of materialism that would be able to support the active constitution and maintenance of the ensemble of social relations, isn't there something to be said for reconsidering intuition-contemplation not as the sole approach to materialism, but as one of the constitutive elements of such an ensemble? In other words, can a truly Marxist and therefore scientific materialism made up exclusively of productive social relations really take place without intuition-contemplation as part of its fundamental constitution? These are the questions that I will attempt to address in this essay.

With these questions, my aim is obviously not to rescue a Feuerbachian (or Hegelian) approach to materialism, but simply to analyse that intuition-contemplation is in fact an important element in any materialism and that, ultimately, Marx's dismissal of it in 1845 constitutes perhaps his most unfortunate undoing because it left praxis, as Antonio Negri and others have shown, caught up in the autistic machineries of capital with no way out but more relations of productions, more praxis. ${ }^{2}$ In other words, by dismissing Anschauung, Marx forestalled the promise that the relation of productions were supposed to achieve, namely the overthrow of capital leaving us in what effectively amounts to an endless heightened state of unproductive production. Without intuition-contemplation, Marx's prized praxis indeed ends up locked in the vortex (or is it hell?) of a dialectical materialism that knows no way out or letting-go, but a constant state of exacerbated activity: materialism qua materialism with capital as the only driving force. This is then the aim of this essay: to show that, in the end, no Marxist materialism can take place without intuition-contemplation as part of its 
fundamental structure, its very survival, and its promised deliverance. Such an ambitiousperhaps too ambitious - aim clearly shows that my intentions with this essay are purely speculative and do not constitute an attempt to draw out a different—or new-interpretation of this famous historical turning point in the history of Marxism.

In order to address these questions and fulfil this speculative aim, I will first attempt to rethink this pairing (intuition-contemplation) that both Marx and Engels reject by addressing the German word they use (and everyone else after them): Anschauung. What is it about this famous word of German philosophy that they find so repellent, so abhorrent? Once a (hopefully) clearer analysis of this word is accomplished, I will attempt to rethink it in the context of a Marxist approach to materialism and more specifically, to the way relations of production and labor take place. The field of research is here limited exclusively to a specific lineage of thought in the vast global Marxist scholarship on this pointy topic, namely the readings put forward by key French Marxists: Bloch, Henry, Althusser, Macherey, and Balibar. As such, it does not aim to be exhaustive of the topic or comprehensive of the various linguistic, philosophical, historical, political, and/or ideological approaches to the issue at hand.

\section{Anschauung or Intuition/Contemplation}

To begin with, let's ask a first simple question: how is one to understand this word, Anschauung that Marx and Engels reject in 1845? The word Anschauung has a long history in philosophy. The word is usually first attributed to Immanuel Kant and the way he understands the apprehension of space and time. ${ }^{3}$ His use of the term constitutes a turning point in the history of philosophy in as much as Kant uses this vernacular term as a German translation of the Latin intuitus, thus acquiring a different connotation to that usually given to the word "intuition" on its own. ${ }^{4}$ In a nutshell, for Kant, space and time are not just thoughts, abstractions, or generalisations; they are first and foremost given in experience. However, space and time are not just objects of direct perception; they are also mental formations of these perceptions. As such, Anschauung designates a mid-point that proceeds from the state of being affected (Empfindung) and prepares for the last phase (Conceptualization). ${ }^{5}$ In other words, it functions as the transmitter between passive sense-impression and the active process of understanding. ${ }^{6}$ The crucial aspect of Kant's use of the word Anschauung is the fact that it is not possible, strictly speaking, to ascribe this process as either belonging to the reality itself $o r$ to the consciousness processing the impression. The undecidability of Kant's term is thus a crucial element in its continued use in philosophy.

Unfortunately, as is well known, there is no equivalent word in English to translate Kant's chosen term. If I limit myself to English and French versions of Kant's works, translators tend to use the words "intuition," "perception," "apprehension," or "contemplation," and more rarely, "at-sight" (Editor 1892, 530) and "the given" (Suchting, 1986, 47). But, as is well known, none of these words fit the meaning of the word Anschauung solely. If I take the two most frequent translation ("intuition" and "contemplation"), it becomes clear that neither term works properly on their own: intuition already exists in German as Intuition and contemplation also already exists in German as Betrachtung. Furthermore, to translate Anschauung as "intuition" in English gives the impression that it refers to something inexplicable, either to some spiritual revelation or some secular lucky hunch. Kant's word has neither of these connotations strictly speaking. Similarly, the problem with the second translation of Anschauung as "contemplation" is that it necessarily refers to the sense of sight 
to the detriment of all other senses and as such always leads to a mental visual representation, thus betraying the indeterminateness of the vernacular German word. While, at first sight, the etymology might support this interpretation (in common usage, Anschauung means "viewing" and the word derives from the verb Anschauen, "to see"), the word Anschauung, at least in the way Kant uses it, does not necessarily imply a direct relation between the eye and thought. $^{7}$

Could there be a way of translating this word in a manner that would not rely exclusively on either a mystical/secular hunch or an immediate visual perception and yet keeps the undecidedness that was crucial to Kant and, as we will see, Feuerbach himself? Considering that there can never be truly satisfactory translations, I would suggest that the word be translated, as I have done thus far in this essay, using both connotations: as "intuitioncontemplation." If this - admittedly, a little cumbersome - translation is acceptable, then Marx and Engels's rejection of Anschauung becomes a little more problematic. On the one hand, the term still retains both the sense of something unknown, still "to-come," which intuition refers to, and the sense of something perceptible by any one of the senses, without necessarily making it into an image. On the other hand, and most crucially, it also renders undecided the issue of whether Anschauung is an entirely passive attitude towards reality or whether it can also be conceived as an active element in the constitution of reality, thus making it into a critical component of any scientific materialism. The hope with this translation is therefore that it somehow retains the two characteristics of the German Kantian word without betraying one of them specifically. ${ }^{8}$

Now that I have attempted to define the term that Marx and Engels reject and explain the use of the cumbersome expression intuition-contemplation for its translation, it is necessary to return to Marx's own use of it in his famous Theses. ${ }^{9}$ I give here again the first thesis, as it constitutes the most incisive use of this term. Marx writes:

"The chief defect of all hitherto-existing materialism - that of Feuerbach included - is that the thing, reality, [and] sensuousness (der Gegenstand, die Wirklichkeit, Sinnlichkeit) are conceived only in the form of the object (Objekts) or of intuition-contemplation (Anschauung), but not as human sensuous activity, practice (Praxis), not subjectively." (Marx 2008, 69).

Marx's three words, der Gegenstand, die Wirklichkeit, Sinnlichkeit stand for what offers itself to consciousness. That is, these three words stand for the "given" as it is grasped by mankind prior to abstraction and conceptualization. From these three words, Marx then interprets the way this "given" is conceived: either as "object" or through "intuition-contemplation" (Anschauung). How is one to make sense of this double rejection?

Marx's alternative between "object" and "intuition-contemplation" is simply an attempt to highlight two misguided approaches to materialism. The first one takes the "given" as an object of understanding and not for what it "is." The second one takes this "given" through an immediate and sensual apprehension devoid of objectification. The fallacy that Marx highlights here is that this "given" cannot be apprehended through either of these approaches alone. It must be approached, as the first thesis shows, as praxis, that is, as an active undertaking or, as he says, as a "human sensuous activity" (sinnlich menschliche). ${ }^{10}$ What is crucial in this first thesis is that Marx doesn't exactly reject the previous two approaches, he simply shows that alone they are insufficient. There cannot be a purely objectifying relation to the "given" and there cannot be a purely fusional and ecstatic rapport to it, called 
"intuitive-contemplative." Only through a predominantly ${ }^{11}$ active approach to this "given" can materialism take off.

But what exactly do Marx and Engels privilege instead exactly? How is one to understand this "human activity or praxis" in the way it was formulated in 1845? The answer, I think, is simple: Marx and Engels reject first "object" because it is too abstract and detached and second, "intuition-contemplation," because it is essentially passive. Neither of these approaches represents activity as such and therefore the true revolutionary process of materialism. For them, the proper way to apprehend reality is through its active processes, the way the subject and the object interact with each other and no objectification or passive intuition-contemplation can ever render this singlehandedly. As Ernst Bloch explains: "the earlier materialism... lacked that permanently oscillating subject-object relationship which is known as labor. For this reason, Feuerbach still interpreted things, reality, and sensuous materiality 'in the form of objects' and apart from 'sensuous human activity'." (Bloch 1971, 67). The old German and "bourgeois" approach to reality, including that of Feuerbach, is therefore devoid of history, alien to the subject-object relationship, and therefore unrepresentative of praxis properly speaking. This leads Bloch to conclude: "Feuerbach ... view[ed] the object in an antiquated 'aristocratic' way... He looked down at action from his lofty position, and saw it only as a sordid undertaking." (Bloch 1971, 72). Marx and Engels' privileging of human activity or praxis is therefore an attempt to foreground a real subjectobject relation as the principal constitution of reality and thus put forward the true and only construction of history, the result of the product of labor.

Can there be another way of going about it? In order to see whether Anschauung can be understood differently than as a useless passive process and to evaluate its importance within the context of a "scientific" approach to materialism, it is necessary to explore further this term, and especially the way it is interpreted by two of Marx's most astute commentators: Etienne Balibar and Michel Henry. Let's start with Balibar.

\section{Praxis, Poiesis, Theoria and the Imperative of Action}

Balibar explains Marx's dismissal of the word Anschauung by referencing the trio: praxis, poiesis, theoria. For him, Marx opens-up a new way of understanding this trio, one which excludes Anschauung precisely because of its passive connotation. He begins by examining Marx's use of the first two terms (praxis, poiesis). Since the Greeks, praxis is basically free action in which man realizes and transforms himself, eventually seeking to attain his own perfection. As for poiesis (from the verb poiein: to make), it is basically necessary action, subject to all the constraints of the relationship with nature, that is, with its material conditions. The perfection it seeks is not that of man, but of things, products for use. Here, then, is the first aspect of Marx's new materialism: not a mere inversion of the hierarchy-i.e. a primacy accorded to poiesis over praxis by virtue of its direct relationship with matter-but the identification of the two, or as Balibar says, "the revolutionary thesis that praxis constantly passes over into poiesis and vice versa..." (Balibar 2017, 41).

Balibar then explains that Marx uses the third term (theoria), not in the old sense of a mental scheme, but in a new sense, that is, as an active philosophical practice evacuated of all forms of passivity. He writes: 
"Now, such a thesis cannot but affect the third term of the classical triptych: theoria or 'theory'... As a counterpart to the 'practice = production' equation established there, The German Ideology makes a decisive sideways move: it identifies theoria with a 'production of consciousness'; or, more precisely, with one of the terms of the historical contradiction to which the production of consciousness gives rise. That term is, in fact, ideology, Marx's second innovation of 1845 , by way of which he was, as it were, proposing to philosophy that it view itself in the mirror of practice." (Balibar 2017, 41).

The third element in the classical trio, theoria, is thus no longer understood as a contemplative intellectual undertaking close to Anschaunn, but as a mirror of activity itself, the effective production of consciousness. If one follows Balibar, it then becomes clear that with Marx, theoria has effectively been evacuated of its contemplative dimension, making it the third element of a purely active undertaking: free (praxis), necessary (poiesis), and conscious (theoria). The old expression of German speculative philosophy, Anschauung, can only therefore be rejected because it is essentially antithetic to the new active trio proposed by Marx. Basically, in an all-active apprehension of "the given," Anschauung must once again be cast aside.

Let's now move to Michel Henry. Henry takes a slightly different view to the problem. Instead of focusing, like Balibar, on the trio praxis, poiesis, theoria and claiming them as exclusively active, he directly focuses on Feuerbach's term, Anschauung so as to make sense of what Marx rejects. Without questioning at any point the translation of Anschauung into the French intuition, Henry asks himself, "so what is this intuition?" By way of an answer, Henry returns, once again, to the classic apprehension of intuition as a form of unveiling or revelation. For him, intuition does not create beings; it reveals being itself. As he says, "intuition has this ultimate phenomenological meaning: it is this and no more than this. It unveils beings, it is this unveiling as such." (Henry 1983, 131). When, later-on, in the same text, Henry asks himself why Marx rejects so categorically this "unveiling" intuition, he explains, in no uncertain terms, that it is because, in the end, intuition is incapable of displaying in itself "the being of action." He writes: "Acting is not intuiting, it is not seeing, it is not looking. In as much as intuition takes place, in as much as we live in it, in as much as we 'intuit,' we are not acting." (Henry 1983, 142). The contrast between action and intuition could not, once again, be clearer: intuition-contemplation (Anschauung) is most simply everything that Marxist materialism should not be. No action, properly conceived within a scientific materialist framework, needs this old term of German idealist philosophy.

But Henry realises that this cannot be so simple. He also notes that in some instances, it is possible that action takes place at the same time as intuition-contemplation. For example, we can contemplate what we are doing as a way of assuring ourselves that our action is indeed going in the general direction of the goal we are pursuing. Intuition-contemplation is therefore a way of correcting or surveying the action. In this context, Anschauung might not be as useless after all. But this is not to be. Very quickly, he writes, as if catching himself offguard that the two, in the end, must be distinguished:

"However, action, considered in itself has nothing to do with this gaze of intuition with the discovery of a spectacle with the appearing of an object. Discovering a spectacle, contemplating it, living in the presence of an object is, precisely, not acting." (Henry 1983, 142-3). 
Intuition-contemplation cannot therefore be understood in any active sense, not even as that of directing or controlling the activity underway. Activity or praxis understood in a purely Marxist sense, must be, once more, devoid of any contemplative intuiting and this simply because, as Henry says, that is how we really act in our lives: "without having the intuition of our action... without looking at it, without giving it to ourselves as an object." (Henry 1983, 143). Crucially, Henry concludes his analyses of the problem of intuition in relation to materialism by saying that if one gets rid of intuition-contemplation, then praxis effectively comes to the fore. The rejection is in fact necessary; it constitutes the fundamental tenet of dialectical materialism. Action is indeed only possible if it is not intuition because the essence (or being) of action is, in the end, totally foreign to that of intuition. In this way, in order to move on from an idealist approach to materialism that generates a living reality petrified by the gaze, it is therefore necessary to give action all its due, that is, to allow it to just "act.",

The question that inevitably should be asked here in response to both Balibar and Henry's reading of Marx's "intuitive-free" materialism of 1845 is this: what if one understood Anschauung or intuition-contemplation in a way whereby it is not exclusively passive, but active-passive as Kant intimated it initially? This question is not intended to go against Marx, Balibar, or Henry and say that their readings are erroneous; but to raise instead the possibility that a) there might not be anything inherently passive about intuition-contemplation or Anschauung and b) that materialism could actively do something with this discarded term of early materialisms without at any one point betraying Marx's sought-after scientific materialism. To address this, I will return not to Kant, but to Feuerbach himself, the main target of Marx and Engels' criticisms. The aim for this return is to allow this rather neglected figure of German philosophy to have a say in this debate that fatally castigated him to the dustbin of history while he was just turning $40 .^{13}$

\section{Feuerbach's Praxis}

Returning to Feuerbach after the monumental undertakings of Marx is always difficult not only because his work often leads to misreadings and misunderstandings, but also because it is often viewed in a negative Marxist angle, as the half-way proponent between an idealist philosophy and a truly materialist project. And yet, once both this negative outlook and the rather complex nature of his writing is overcome, Feuerbach manages to reveal some rather astute insights into the problems that Marx and Engels were addressing mid-nineteenth century. If one focuses exclusively on their use of Anschauung, it becomes clear, for example, that Marx's blanket condemnation is probably not as justified as he thinks and that Engel's vitriolic copy-cat rejection of all things Feuerbachian reveals how little he understood of his work. Let's explore Feuerbach's approach to the issue of the apprehension of reality through the prism of Anschauung and thus his own idiosyncratic conception of materialism.

Firstly, contrary to what Engels thinks, Feuerbach does not pitch activity and passivity against one another and he does not place subject-object relations against intuitioncontemplation. When it comes to Anschauung, Feuerbach always starts by simply pitching it against thought. Thought stands for objectification and intuition-contemplation stands for a letting go of this objectification. He writes in the twenty-fifth Principles of the Philosophy of the Future: ${ }^{14}$ 
"In thought, I am an absolute subject; I let everything exist only as my object or predicate; that is, as object or predicate of myself as a thinking being. I am intolerant. In relation to the activity of my senses, such as intuition-contemplation (Anschauung), I am, on the other hand, a liberal; I let the object be what I myself am-a subject, a real and selfactivating being." (Feuerbach 1986, 40, translation modified).

As this extract shows, contrary to thought, which only serves as possessing objects and rendering us intolerant, Anschauung does something positive: it allows the person intuitingcontemplating to become a subject. In other words, intuition-contemplation, this letting go of objectification, allows us to be self-activating subjects. ${ }^{15}$ Anschaunng is thereby an empowering process that is neither passive nor possessive and aims ultimately to curb the excesses of thought and objectification, thus avoiding taking oneself (and others) as object(s).

In his Provisional Theses for the Reformation of Philosophy, written during the same period, Feuerbach further confirms this dual role of thought and intuition-contemplation, the former being a mediating and objectifying process, the latter being an unmediated access to subjectivity. He writes:

"Thought is the principle governing school and all systems. Intuition (Anschauung) is the principle of life. In intuition, I am at the mercy of the object, in thought I determine the object. In thought, I am 'me,' in intuition, I am 'non-me'... Intuition gives the unmediated essence of existence as one, thought gives the mediated essence of existence as distinction." (Feuerbach 1972, 120-1, my translation into English). ${ }^{16}$

Once again, Feuerbach clearly brings together both thought and intuition without giving priority to one or the other. The two have clearly specific roles in the apprehension of reality. Feuerbach further explains this dual role in his Principles of the Philosophy of the Future, again when he writes in principle forty-eight: "Thought does not follow a straight line within its self-identity, but is always interrupted by sensuous intuition (Anschauung)." (Feuerbach $1986,64)$. In other words, thought cannot effectively take place independently of intuitioncontemplation: it needs it to carry out its objectifying tasks. But why should this matter? Because, for Feuerbach, without intuition-contemplation, thought effectively only leads to itself, it only operates in complete circularity, and such autism never manages, in the end, to access reality. In order to have a proper access to reality, in order to avoid the dangers of a system locked in the circularity of thought, it is necessary to have something radically alien to thought: intuition-contemplation.

So this is what Anschauung is for: it not only gives the possibility of thought, it also and above all gives access to reality, including being itself. Without the intertwinement of the two, reality cannot be accessed, materialism cannot move, production and labor remain in deadlock, always pointing back to itself. Feuerbach summarises his approach to the twin issue of thought/intuition-contemplation:

"Sensuous intuition (Anschauung) takes things in a broad sense, but thought takes them in the narrowest sense; intuition leaves things in their unlimited freedom, but thought imposes on them laws that are only too often despotic; intuition introduces clarity into the head, but without determining or deciding anything; thought performs a determining function, but it also often makes the mind narrow; intuition in itself has no principles and thought in itself has no life; the rule is the way of thought and exception to the rule is that of intuition." (Feuerbach 1986, 65). 
So intuition-contemplation is really not the only way Feuerbach accesses reality and it does not found, contra Marx, his materialism exclusively. There cannot be reality without both thought and intuition-contemplation and it is the two, taken together, that are the activepassive agents giving us the materiality of the world. As he writes, again in the Principles of the Philosophy of the Future:

"The thought that is identical, and exists in an uninterrupted continuity, with itself, lets the world circle, in contradiction to reality, around itself as its center; but the thought that is interrupted through ... the anomaly of intuition (Anschauung), transforms this circular movement into an elliptical one in accordance with the truth." (Feuerbach 1986, 65).

Such an approach to reality gives us a type of philosophy that cannot therefore be confined exclusively, as Marx and others imagined, to a type of passive project, the aristocratic gazing of the world from above, untainted by the objectifying modes of production. On the contrary, Feuerbach's philosophy is one that identifies Anschauung and thought as the two components structuring not only praxis, but also poiesis and theoria. Feuerbach's materialist project is indeed one that neither reduces everything to "pure action" (Balibar) nor ejects "passive" intuition as the real obstacle to the being of action (Henry), but intertwines both object (thought) and intuition-contemplation (Anschauung) to apprehend, as Marx desperately wants, "the thing, reality, [and] sensuousness (der Gegenstand, die Wirklichkeit, Sinnlichkeit)."

\section{Conclusion: Anschauung and Marx's ensemble}

What does this return to Feuerbach's thinking allows us to do, now, nearly 135 years after Marx's passing? What kind of consequences does this attempt to re-think the word Anschauung that Marx, Engels, Althusser, Henry, and Balibar reject with such force, allows us to accomplish? Can one re-think the intuitive-contemplative-and thereby supposedly, feminine ${ }^{17}$ - approach that Feuerbach is seen to impose on reality and recast it within the context of Marx's 1845 new materialism? In order to evaluate the type of consequences that might be inferred from such a change in the meaning of the word Anschauung, it is necessary to reconsider Marx's crucial sixth thesis on Feuerbach. He writes:

"Feuerbach resolves the essence of religion into the essence of man (menschliche Wesen= 'human nature'). But the essence of man is no abstraction inherent in each single individual. In reality, it is the ensemble of the social relations." (Marx 2008, 71).

As has been commented many times, this famous thesis attempts to designate the importance of the displacement that is needed between an understanding of man as a single abstract monad and as an ensemble of real social relations. ${ }^{18}$ The shift from singularity to multiplicity forces philosophy to move from the reified realm of abstraction that has characterised it to date, into a materialist approach to reality that leaves no space for idealism ("in reality" - "In seiner Wirklichkeit"), thus opening up a truly revolutionary work that Marx envisaged as tocome. In other words, with this famous thesis, there can be no more (in-)finite abstract supraentities, such as Being or Spirit lording over or structuring reality, but a concert of concrete social relations, the true modus-operandi of the new materialism of the future. ${ }^{19}$ 
However, while the move from abstraction-singularity to materialism-multiplicity is an undeniable key change in Marx's thought, ${ }^{20}$ one must not forget that the ensemble he suggests as an alternative to idealist materialism is effectively never fixed; it is always in movement. ${ }^{21}$ In other words, the ensemble of social relations is always in a permanent state of restructuration (Selbstveränderung). Marx uses this expression three theses earlier:

"The coincidence of the changing of circumstances and of human activity or self-change (Selbstveränderung) can be conceived and rationally understood only as revolutionising practice." (Marx 2008, 70).

What this previous thesis shows is that in order for social relations to be essentially "revolutionary," or "unwälzende" as Engels suggests in his own editorial intervention to the same thesis, it needs to be always already open to the contingent, to what is unknown, to what irremediably alters the ensemble into something hereto unheard off or unrecognizable, a new ensemble, for example. The self-restructuration of the ensemble is thus crucial to fight back the inevitable ossifications - mostly conceptual, but also political and ideological - that always threatens it.

Such openness to the contingent (or to what is "to-come," to use Derrida's vocabulary ${ }^{22}$ ) is usually interpreted as the main motor of revolutionary Marxism, namely, it opens-up to the teleological future that it promises. This is what leads Ernest Bloch to affirm that the ensemble and therefore reality is indeed always changeable ("veränderbar"), something which neither classical materialism nor idealism ever admitted. ${ }^{23}$ Similarly, Louis Althusser equally affirms the importance of understanding Marx's 1845 ensemble as a theory that must always already be understood as "an action to be achieved, a displacement to be put in effect... The real, this way!" (Althusser 2005, 210). Finally, this is what Balibar also remarks, in his own analyses of this particular thesis when he says that the indefinite character of Marx's French word ensemble needs to be understood as essentially "open to infinity." (Balibar 2012, 11). But how does the self-change (Selbstveränderung) of the ensemble take place? How does this openness to the contingent or what is to-come occur? What gives "the way" to the real? How does infinity open-up?

This is where Feuerbach's own interpretation of Anschauung becomes crucial. In order to make sense of the movement implied in Marx's Selbstveränderung, I feel it is necessary to rethink the ensemble as essentially structured by both rational thought and intuitivecontemplation. If one indeed keeps in mind our re-reading of this much maligned Feuerbachian term, then the revolutionary ensemble that Marx proposes must also take into account, not only subject-object relations, that is, the modes of productions and labor, but also all that which, always already escapes them and this includes the intuitionscontemplations that structure them. If Feuerbach is right in believing that no rational thought, and therefore no labor relation can take place without intuition-contemplation, then Marx's ensemble cannot truly function without it, not as a foundational empty abstraction $a ̀$ la Hegel, but, most simply, as a key constitutive element of the ensemble. The ensemble needs Anschauung to keep this permanent state of restructuration (Selbstveränderung) that prevents it from ossifying into relations of productions for their own sake, that is, into a revolution that knows no resolution in sight. In other words, the displacement that is offered here with Feuerbach's own interpretation of this word is that the ensemble is no longer just structured by history, it is also structured by what surprises it, that is, by what interrupts its very process every second of time and says, intuitively, "this way!" There can be no new ensemble without 
it. It stands for one of the motors in the self-change of the production of material existence; its very opening onto infinity.

In this way, once Marx's condemnation of intuition-contemplation is rethought in a sense that is neither passive nor absolute, but undecidedly active and passive at once, we can then finally move, as his last thesis (eleven) famously suggests, from a philosophy that only seeks to interpret the world to one that truly seeks to change it. But this time, it will no longer be a revolution against an old philosophy, that is, pure action against aristocratic contemplation, but a revolution that seeks to empower the ensemble both as action for change and as intuition-contemplation for change, a dual gesture that concerns not just modes of production or forms of labor, but also the activity-passivity of self-restructuration of the ensemble itself. When this will materialise itself, the ensemble will then truly reflect what it is made up: humans that are able to put forward a rational thought and interrupt it altogether, tackle the real and intuit it at the same time, participate in production and labor without fossilizing them in conceptual oppressions, and create $u s e$-values without also assuming them to be exclusively and necessarily exchange-values. It is only then that the Marxist materialist revolution intimated in 1845 will acquire, beyond Capital, its fulfilling dimension, one in which it recognizes each component of the ensemble as made up of humans who don't just make history, but invent and surprise it too, each and every one of them in modes hereto unheard off. After all, growth, however it is understood, is driven not by productivity alone, but above all by knowledge at the cusp of reason.

Can this foster a new name and therefore a new horizon for Marx's praxis? If "the given" (der Gegenstand, die Wirklichkeit, Sinnlichkeit) is no longer understood predominantly through activity, that is, as praxis-poiesis-theoria, but above all through the activity-passivity that allows the ensemble to re-structure itself every second of time (rational thought + intuition-contemplation), should it then not foster a different appellation, a new term for the future? In a surprising reading of Heidegger's work, Jean-Luc Nancy translates, at one point in his analyses, the Greek term praxis by "to conduct oneself" (se conduire), thus emphasizing through its etymology (from the Latin verb conducere, "bringing together") the social mode of any praxis. ${ }^{24}$ If Marx's primary emphasis is indeed praxis, and therefore subject-object relations and if, on our account, these relations must be understood with the added benefit of intuition-contemplation (Anschauung), do we then not have here an invitation to "conduct oneself" over and beyond the simple call for more active praxis, poiesis, and theoria? In other words, to form an ensemble, to be part of such an ensemble, one must effectively not just "act," but also and above all, "conduct oneself" and that implies a certain amount of intuition-contemplation, Anschauung. The future of any ensemble is therefore not an apocalypse or a communist ideal imagined on the horizon and arrived at by mere productive toiling alone, but most simply the recurrent call to "conduct ourselves" so that the said ensemble continues to maintain itself forever in its very own self-restructuration (Selbstveränderung). 


\section{Notes}

${ }^{1}$ On this topic, see Macherey 2008, 131-2.

2 There is, unfortunately, no space here to unpack this well-known argument that sees 19171929 as a crucial turning point in history in which Marxism floundered because instead of the overthrow of capital liberating its productive potential, these crises led in fact to the selfdestruction of that very potential. See Negri 1988.

${ }^{3}$ With such a statement, I deliberately circumscribe the issue of Anschauung to only reflect pure intuition (i.e. intuition that cannot be inferred or explained a posteriori). In doing so, I therefore bypass the much larger issue of intuitions as they are analyzed in the fields of linguistic or behaviorist theories. For Kant's pure intuition, see Kant 1993, especially, A19/B77.

${ }^{4}$ And, therefore, to the interpretation of intuition given by Descartes, namely, as a type of self-evident knowledge gained through rational — but not-deductive-reasoning. See Descartes 1997.

${ }^{5}$ As is well known, Henri Bergson famously inverts this interpretation when he says that intuition - and not Anschauung - is not something that reveals itself to consciousness, but is the act of entering it and in doing so, "seizing ourselves from within." There is, unfortunately, no space here to analyse these post-Marxist differences. See Bergson 2002. ${ }^{6}$ The word is also, obviously, picked up by many other philosophers all the way up to the twentieth-first century. Besides the two authors that concerns us here directly, namely Feuerbach and Marx, it is worth noting that the word obviously receives its most significant development with Edmund Husserl. Husserl pushes Kant's understanding of this term in altogether different direction. Instead of making it a mid-way between sense-data and mental constructions, he sees it as the medium in which reality impinges on one's consciousness. In order to show this, Husserl re-emphasizes the distinction between the German vernacular Kantian term, Anschauung and the Latin intuitio. Unlike Kant, Husserl uses the former primarily as an analogical extension of shauen, that is, seeing in the sense of immediate visual awareness of reality, thus retaining the primacy of visuality, close to eidetic "seeing" (Wesensschau), Ideas I, §19. He uses the latter primarily as a transcendental determination of the essence of things, thus detaching it from any specific visual reference. There is, unfortunately, no space here to analyse these post-Marxist distinctions. See Husserl 1983. For an analysis of Husserl's use of these terms, see Levinas 1973 and Hintikka 2003.

${ }^{7}$ As Georges Labica says, "Taken at its most familiar and literal sense, Anschauung means... simply perception without specifying a particular type of perception." Labica 2014, 38, my translation.

${ }^{8}$ Unfortunately, there is no space here to make a crucial comparison between this interpretation of Anschauung and Spinoza's third type of knowledge (intuition) which he develops, against Descartes, in the Scholia of Proposition XXIX of his Ethics. In a nutshell, Spinoza argues that his third type of knowledge takes place at the edge of time, both sub duratione (from the premise of a spatial and temporal perspective) and sub-species eternitatis (from non-spatial and temporal premises). To illustrate this point, Spinoza, as is well known, uses the example of a circle existing in space and time. Inside it, necessary, but invisible intersecting chords form equally necessary, but invisible rectangles. Unlike the circle, the chords and rectangles don't actually exist in space and time. They are dependent on the circle to exist, but "are" not "there," properly speaking. Spinoza's third kind of knowledge is therefore not a process that singlehandedly touches upon an elsewhere, but operates at the indecision of what is in and out of space and time. As such, Spinoza's vision therefore involves both an adequate set of ideas about the properties of things (i.e. knowledge of the second kind, in Spinoza's taxonomy) and one that defies all forms of rationality (i.e. 
knowledge of the third kind, intuition). See Spinoza 1992. For an analysis of Spinoza's understanding of intuition, see, amongst others, Soyarslan 2013. For a comparison between Spinoza and Feuerbach, see Bensussan 2008 and for insightful comparisons between Spinoza and Marx, see amongst a vast literature: Negri 1991, Holland 1998, Fischbach 2005, Tosel 2008.

${ }^{9}$ For an analysis of Marx's Theses in English, see Suchting 1979 and 1986. Although I don't agree with his analyses of the Theses, mainly because he translates Anschauung with "the given," thus missing out on an important aspect of Marx's critique, Suchting's studies constitute excellent introductions to these early works in English.

${ }^{10}$ I leave aside here, for lack of space, the enormous issue of sensuousness and its relationship to reality and materialism.

${ }^{11}$ I use this word in order to emphasize that Marx does not intend, as is well known, pure action as such or actus purus in the idealist manner of Moses Hess or Karl Grün.

${ }^{12}$ The problem with the rest of Henry's commentary is that he then moves on, contrary to Marx, to conflate both object and intuition as well as intuition and seeing as if these were all interchangeable or synonymous. Firstly, Marx clearly writes in Thesis One, "object or intuition" (Objekts oder der Anschauung). There is no amalgamation of the theoretical process of objectification and that of intuition, but a clear alternative. Secondly, Marx never confuses intuition with seeing exclusively. As the ambivalent use of the word Anschauung shows, intuition is not necessarily contemplation. For the way Henry finishes his argument conflating all these terms, see Henry 1983, 145 and again, 153-7.

${ }^{13}$ On this history, see Chamberlain 1941, Kamenka 1970, Wartofsky 1977, and Dellaï 2011.

${ }^{14}$ Taken as a whole, most of Feuerbach's analyses of the term Anschauung - at least, in the crucial period prior to the 1848 revolution - can be found in his Principles of the Philosophy of the Future. His most well-known book, The Essence of Christianity, only contains nine separate occurrences of the word Anschauung. There is clearly an evolution between The Essence and The Principles showing Feuerbach's attempt to explain his position with regards to this crucial word of German philosophy. See Feuerbach 2008.

${ }^{15}$ There is unfortunately no space here to compare this Feuerbachian idea with Fichte's Thathandlung, which also intertwines thought and intuition. Suffice to say that while Fichte's leads to transcendental subjectivist idealism, Feuerbach's leads instead to social materialism. See Fichte 1994, especially 47-9.

${ }^{16}$ I give this translation instead of the one found in English for the simple reason that it is more representative of Feuerbach's overall thought. Here is Lawrence S. Stepelevich translation: "Thinking is the principle of the school, of the system; intuition, the principle of life. In intuition, I am determined by an object, in thinking I determine the object. In thinking, I am an 'I,' in intuition a 'not-I.' ... The intuition yields simply the essence immediately identical with existence. Thinking yields the essence mediated by its distinction and its separation from existence." (Stepelevich 1983, 164).

${ }^{17}$ Unfortunately, there is no space here to explore this problematic analogy. Bloch is the only author who makes this comparison between passive intuition-contemplation and the feminine, albeit without realizing the problems that such a comparison entails. He indeed writes without hesitation that "Feuerbach effeminizes humanity." (Bloch 1971, 86). While the Feuerbachian reading proposed in this essay may suggest that issues of gender have been subsumed under a generic (and therefore male) characteristic of human relations ("we" all intuit/reason), the sought-after renewal of Marx's ensemble it ultimately aims to achieve should be seen, on the contrary, as a mandate to study the role and participation of all gender and gender identifications in their own oppressions, their engagement in social relations, their 
need for self-change and their subjection as part of the ensemble. For a rare attempt to read Marx's 1845 Theses through the lens of gender, see Haug 2015.

${ }^{18}$ Thus, echoing, as has been commented a few times before, Feuerbach's own understanding of being: "Sein ist Gemeinschaft," Being is community. (Feuerbach 1980, 122).

${ }^{19}$ Which Marx will later formulate with expressions such as: "The human being is

in the most literal sense a Zoon politikon not merely a gregarious animal, but an animal which can individuate itself only in the midst of society." Marx 1993, 84.

${ }^{20}$ A move, let us hasten to emphasize, made way before Heidegger's complex analyses of mit-dasein and of its many avatars including Nancy's being-singular-plural. See amongst others, Nancy 1992.

${ }^{21}$ For an interpretation of the Sixth Thesis that evinces this contingent movement in order to recuperate a supposedly totalising sense to human nature in Marx, see the very thorough Geras 1983. For Marx's concept of man, see Fromm 2003, 1-70.

${ }^{22}$ See Derrida 1994.

${ }^{23}$ See Bloch 1986, 249-86.

${ }^{24}$ See Nancy 1999. 


\section{References}

Althusser, Louis. 2005. For Marx. Trans. Ben Brewster. London: Verso.

Balibar, Etienne. 2012. "From Philosophical Anthropology to Social Ontology and Back: What to Do with Marx's Sixth Thesis on Feuerbach?” In Postmodern Culture 22, no. 3 (May 2012): unpaginated.

—. 2017. The Philosophy of Marx. Trans. Chris Turner. London: Verso.

Bensussan, Gérard. 2008. "Feuerbach et le 'secret' de Spinoza." In André Tosel, PierreFrançois Moreau, and Jean Salem, eds. Spinoza au XIXe siècle, 113-23. Paris: Publications de la Sorbonne.

Bergson, Henri. 2002. The Creative Mind: Introduction to Metaphysics. Trans. Marie Casata. London: Kensington Publishing.

Bloch, Ernst. 1971. On Karl Marx. Trans. John Maxwell. New York: Herder and Herder.

Chamberlain, William B. 1941. Heaven Wasn't His Destination: The Philosophy of Ludwig Feuerbach (London: Routledge).

Dellaï, Sameh. 2011. Marx, Critique de Feuerbach (Paris: L'Harmattan).

Derrida, Jacques. 1994. Spectres of Marx, The State of the Debt, the Work of Mourning \& the New International. Trans. Peggy Kamuf. New York: Routledge.

Descartes, René. 1997. Rules for the Direction of the Mind. Trans. Harold H. Joachim. Bury St. Edmunds: St Augustine's Press.

Editor. 1892. “What does Anschauung mean?” In The Monist 2, no. 4 (July): 527-532.

Feuerbach, Ludwig. 1972. Manifestes philosophiques. Trans. Louis Althusser. Paris: Presses Universitaires de France.

—. 1980. Thoughts on Death and Immortality: From the Papers of a Thinker, Along with an Appendix of Theological Satirical Epigrams, Edited by One of His Friends. Trans. James A. Massey. Berkeley: University of California Press.

—. 1986. Principles of the Philosophy of the Future. Trans. Manfred Vogel. Indianapolis: Hackett Publishing.

—. 2008. The Essence of Christianity. Trans. George Eliot. Mineola: Dover Publications.

—. 2012. The Fiery Brook: Selected Writings. Trans. Zawar Hanfi. London: Verso.

Fichte, J. G. 1994. Introductions to the Wissenschaftslehre. Trans. Daniel Breazeale. London: Hackett. 
Fischbach, Franck. 2005. La Production des hommes: Marx avec Spinoza. Paris: Presses Universitaires de France.

Fromm, Eric. 2003. Marx's Concept of Man. London: Continuum.

Geras, Norman. 1983. Marx and Human Nature: Refutation of a Legend. London: Verso.

Haug, Frigga. 2015. “The Marx within Feminism.” In Shahrzad Mojab, ed. Marxism and Feminism, pp. 76-101. London: Zed Books, 2015.

Holland, Eugene. 1998. “Spinoza and Marx.” In Cultural Logic 2, no. 1 (Fall): 1-15.

Henry, Michel. 1983. Marx: A Philosophy of Human Reality Trans. Kathleen McLaughlin. Bloomington: Indiana University Press.

Hintikka, Jaakko. 2003. "The notion of intuition in Husserl." In Revue internationale de philosophie 2, $\mathrm{n}^{\circ}$ 224: 57-79.

Husserl, Edmund. 1983. Ideas Pertaining to a Pure Phenomenology and to a Phenomenological Philosophy: First Book: General Introduction to a Pure Phenomenology. Trans. F. Kersten. Dordrecht: Kluwer

Kamenka, Eugene. 1970. The philosophy of Ludwig Feuerbach. London: Routledge \& K. Paul.

Kant, Immanuel. 1993. Opus Postumum. Trans. Eckart Förster and Michael Rosen. Cambridge: Cambridge University Press

Labica, Georges. 2014. Karl Marx: Les Thèse sur Feuerbach. Paris: Editions Syllepse.

Levinas, Emmanuel. 1973. The Theory of Intuition in Husserl's Phenomenology. Trans. André Orianne. Evanston: Northwestern University Press.

Macherey, Pierre. 2008. Marx 1845: Les Theses de Feuerbach. Paris: Editions Amsterdam.

Marx, Karl. 2007. "Critique of the Hegelian Dialectic and Philosophy as a Whole." In The Economic \& Philosophic Manuscripts of 1844. Trans. Martin Milligan. Mineola: Dover Publications.

Marx, Karl; and Friedrich Engels. 1976. Collected Works, Volume 5. London: Lawrence \& Wishart.

—. 1993. Grundrisse. Trans. Martin Nicolaus. London: Penguin Books.

—. 2008. On Religion. Mineola: Dover Publications.

Nancy, Jean-Luc. 1992. "The Compearence from the existence of communism to the community of existence." In Political Theory 20, no. 3 (1992): 371-98. 
—. 1999. "Heidegger's Originary Ethics.” In Studies in Practical Philosophy 1, no. 1: 12-35.

Negri, Antonio. 1988. Revolution Retrieved: Writings on Marx, Keynes, Capitalist Crisis and New Social Subjects (1967-83). London: Red Notes.

—. 1991. The Savage Anomaly: ThePower of Spinoza's Metaphysics and Politics. Trans. Michael Hardt. Minneapolis: University of Minnesota Press.

Soyarslan, Sanem. 2013. "The Distinction between Reason and Intuitive Knowledge in Spinoza's Ethics." In European Journal of Philosophy 2: 27-54.

Spinoza, Benedict de. 1992. Ethics. Trans. Samuel Shirley. Indianapolis: Hackett Publishing Co.

Stepelevich, Lawrence S. Ed. 1983. The Young Hegelians: An Anthology. Cambridge: Cambridge University Press.

Suchting, W. A. 1979. "Marx's Theses on Feuerbach: A New Translation and Notes towards a Commentary." In John Mepham and David-Hillel Ruben, eds., Issues in Marxist Philosophy, vol. II. Brighton: Harvester Press.

—. 1986. Marx and Philosophy: Three Studies. London: Macmillan.

Tosel, André. 2008. "Pour une étude systématique du rapport de Marx à Spinoza: Remarques et hypotheses." In André Tosel, Pierre-François Moreau, and Jean Salem, eds. Spinoza au XIXe siècle, 127-47. Paris: Publications de la Sorbonne.

Wartofsky, Marx W. 1977. Feuerbach. Cambridge: Cambridge University Press. 